\title{
Moderasi Islam dalam Dimensi Berbangsa, Bernegara Dan Beragama Perspektif
}

Maqashid Asy-Syari'ah

\author{
M. Luthfi Afif Al Azhari \\ Institut Agama Islam Ngawi \\ luthfiafif@iaingawi.ac.id
}

\begin{abstract}
Abstrak
Wasațiyyah melekat pada islam semenjak ia lahir dan akan terus melekat sampai hari kiamat nanti. Dalam sejarahnya, pasca terjadinya perpecahan dalam tubuh umat islam yang melahirkan banyak madzhab dan aliran, sifat Wasatiyyah melekat pada golongan yang berhaluan Ahlus Sunnah wa aljama'ah, termasuk didalamnya aliran teologi Asy'ariyah dan Maturidiyah. Maqashid syari'ah muncul akibat perdebatan di antara pakar fiqh mengenai syari'ah, yang memiliki 'illat (kausa) tertentu ataukah tidak. Perdebatan tersebut menimbulkan berbagai macam aliran tak terkecuali di kalangan ulama' ushul fiqh. Maqhasid al-ahkam dianggap sebagai dasar dalam penetapan suatu hukum, dan dapat dikategorikan sebagai landasan utama dalam hukum. Sebagaimana keterangan mengenai al-kulliyyat al-khams beserta batasannya, hifzh ad-din (perlindungan agama), hịifh an-nafs (perlindungan jiwa), hifzh al-'aql (perlindungan intelektual), hifzh an-nasl (perlindungan genetik), dan hịfzh al-māl (perlindungan harta)
\end{abstract}

Kata Kunci: Moderat, Islam, Maqashid Asy-Syari'ah

\section{Pendahuluan}

Agama Islam memiliki banyak ciri

khas yang membedakannya dengan agama lainya. Ciri khas Islam yang paling menonjol adalah tawassut (jalan tengah), ta'adul (berkeadilan), dan tawazun (seimbang) . ketiga ungkapan tersebut memiliki arti yang sangat berdekatan, ketiganya bisa disarikan dan disatukan menjadi wasațiyyah (moderat).

Ciri khas wasatiyyah Islam sendiri dinyatakan oleh Allah dalam al-Qur'an:

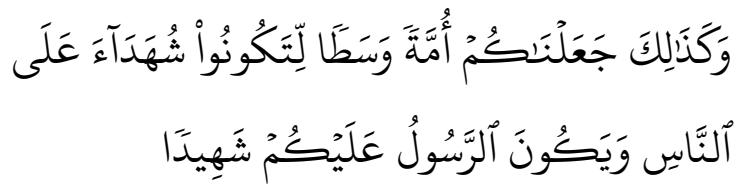

Terjemahnya: Dan demikian (pula) Kami telah menjadikan kamu (umat Islam), umat yang adil dan pilihan agar kamu menjadi saksi atas (perbuatan) manusia dan agar Rasul (Muhammad) menjadi saksi atas (perbuatan) kamu (Q.S. Al-Baqarah: 143).

Wasațiyyah berarti jalan tengah atau keseimbangn antara dua hal yang berbeda atau bertentangan, seperti keseimbangan antara ruh dan jasad, 
dunia dan akhirat, ilmu dan amal, dan seterusnya. ${ }^{1}$

Karakter Wasatityyah melekat pada islam semenjak ia lahir dan akan terus melekat sampai hari kiamat nanti. Dalam sejarahnya, pasca terjadinya perpecahan dalam tubuh umat islam yang melahirkan banyak madzhab dan aliran, sifat Wasatiyyah melekat pada golongan yang berhaluan Ahlus Sunnah wa aljama'ah, termasuk didalamnya aliran teologi Asy'ariyah dan Maturidiyah. Di Nusantara, ciri khas Wasațiyyah terlihat jelas pada tradisi dan platform Jam'iyyah Nahdlatul 'Ulama (NU). NU merupakan organisasi keagamaan terbesar yang mempunyai basis massa hingga tingkat pedesaan dan banyak mengembangkan model pendidikan pesantren. ${ }^{2}$

Fenomena Wasatiyyah mewarnai semua dimensi ajaran islam yang mencakup semua aspek kehidupan. Dengan bahasa lain, karakter Islam Wasațiyyah (moderat) sudah bertahuntahun menjadi cita rasa penerapan ajaran agama di Nusantara yang berasaskan Pancasila.

\section{Landasan Teori}

\section{Maqāshid asy-Syarī'ah}

Maqūshid asy-syarī'ah adalah nilainilai universal yang menjadi tujuan dari legislasi (pensyariatan) seluruh hukum agama. Nilai-nilai universal ini terangkum dalam lima prinsip dasar (alkulliyyat al-khams). Yaitu, hifzh ad-din (perlindungan agama), hifzh an-nafs (perlindungan jiwa), hifzh al-'aql (perlindungan intelektual), hifzh an-nasl (perlindungan genetik), dan hifzh al-māl (perlindungan harta). ${ }^{3}$

Maqāshid asy-syari'ah sendiri menurut salah satu pendapat ditengarai muncul akibat perdebatan di antara pakar figh mengenai syari'ah, yang memiliki 'illat (kausa) tertentu ataukah tidak. Perdebatan tersebut menimbulkan berbagai macam aliran tak terkecuali di kalangan ulama' ușul figh. Perkembangan selanjutnya diwarnai oleh dua tokoh $\mathrm{Abu}$ al-Hasan al-Basri dan al-Ghazali.

Pada perjalanan sejarah, syarīah didefinisikan pada suatu definisi yang lebih mengerucut pada suatu pengertian seperangkat tatanan hukum Islam praktis, atau seperangkat peraturan

3 Tim Forza Pesantren, Ijtihad Politik Islam Nusantara, (Kediri: Lirboyo press, 2015), 80

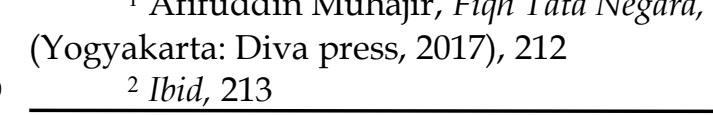


berdasarkan wahyu Allah dan atau menunjukkan, agama memiliki concern Sunnah Rasul tentang tingkah laku terhadap dua tata kehidupan.

manusia mukallaf yang diakui dan diyakini mengikat untuk segenap muslim. Maka, maqāshid asy-syarīah dapat dikorelasikan dengan maqāshid alahkam. Yaitu aturan yang ditetapkan sebagai inti dari tujuan ditetapkannya suatu hukum dengan banyak peraturan yang ketat. Segenap aturan tersebut dikodifikasi dan dianggap sebagai aturan baku bagi suatu golongan.

Maqāshid al-ahkam dianggap sebagai dasar dalam penetapan suatu hukum, dan dapat dikategorikan sebagai landasan utama dalam hukum. Oleh karena itu, sangatlah wajar jika ditemukan poin utama tujuan pembentuk hukum dalam suatu ketetapan hukum itu sendiri. ${ }^{4}$

\section{Hifzh al-din}

Agama adalah ajaran atau sistem yang mengatur tata keimanan (kepercayaan) dan peribadatan kepada Tuhan Yang Maha Esa, serta mengatur tata kaidah yang berhubungan dengan pergaulan antar manusia serta lingkungannya. Dari pengertian ini
1. Tata kehidupan manusia sebagai makhluk Tuhan, yaitu dengan wujud peribadatan dan mematuhi hukumhukum Tuhan (syarī'at).

2. Tata kehidupan manusia sebagai makhluk sosial, yaitu dengan menanamkan moral-etik dalam kehidupan bermasyarakat.

Eksistensi manusia sebagai makhluk Tuhan dan manusia sebagai makhluk sosial, tidak mungkin bisa dilepaskan dari agama. Agama menjadi kebutuhan primer bagi kehidupan manusia, sehingga eksistensi agama harus dilindungi. Melindungi eksistensi agama, secara tidak langsung berarti juga melindungi eksistensi manusia.

Dalam penerapannya, hifzh ad-din diwujudkan dengan penjagaan dari dua sisi. Pertama, penjagaan dari sisi kelestariannya (janib al-wujud). Dalam kerangka janib al-wujud, islam mewajibkan manusia beriman, melaksanakan shalat, membayar zakat, puasa, menunaikan ibadah haji, dan kewajiban agama yang lain. Kedua, penjagaan dari sisi ancaman yang dapat 
merusaknya (janib al-'adam). Dalam melawan kebodohan. Sedangkan jihad kerangka janib al-'adam, islam dalam pengertian khusus berarti qital. mewajibkan jihad ketika mendapatkan Yaitu perang fisik melawan non-muslim serangan dari non-muslim, menetapkan yang memusuhi dan menyerang umat hukuman mati dalam kasus apostasi Islam.

(murtad atau keluar dari agama),

Dalam ajaran Islam memang mendukung kebebasan agama, dan lain terdapat instruksi untuk berjihad dalam sebagainya. 5

\section{a. Jihad}

Jiḥad berasal dari kata jậada yang secara literal berarti bersungguhsungguh atau berusaha keras. Dari akar kata "jahada" ini selanjutnya lahir kata turunan berupa jihad, ijtihad, dan mujahadah.

Mujahadah adalah memerangi hawa nafsu dengan tariqah: mengosongkan segala sifat-sifat tercela (takhalli) dan menghiasi diri dengan sifat-sifat terpuji (tahalli) hingga bisa menyaksikan kebesaran Tuhan (tajalli). Perang melawan hawa nafsu inilah yang disebut Nabi sebagai jihad kubra (perang besar). Ijtihad adalah mengerahkan segala daya intelektual untuk menggali dan menemukan inspirasi-inspirasi hukum dari al-Quran dan as-Sunnah. Ijtiḥad juga bisa diinterpretasikan sebagai perang arti berperang melawan non-muslim, baik dalam al-Quran maupun as-Sunnah. Namun yang perlu digaris bawahi adalah, jihad dalam arti perang melawan non-muslim, dalam ajaran islam sama sekali bukan karena faktor kekufuran mereka. Artinya, jihad yang dilegalkan Islam bukan semata-mata karena mereka beda agama, tetapi karena mereka memusuhi dan menyerang umat Islam.

Jiḥad dalam Islam adalah himayah ad-da'wah (pelindung dakwah). Artinya, jihad merupakan usaha untuk mempertahankan atau membela diri manakala kebebasan dakwah (agama) dirintangi menggunakan kekuatan senjata. Dengan kata lain, karakter jihad dalam Islam bersifat defensif (difa'i), yakni sebagai bentuk pertahanan dan bela diri karena mendapatkan serangan terlebih dahulu. Karakter jiḥad dalam Islam 
bukan bersifat ofensif (hujumi), yakni menyerang untuk melakukan ekspansi. ${ }^{6}$

Ketika Islam tidak mendapatkan serangan non-muslim terlebih dahulu, atau non-muslim telah berhenti melancarkan serangan, maka Islam tidak mengajari umatnya untuk melakukan teror, serangan atau memusuhi pemeluk agama apapun.

Pandangan seperti ini sekaligus menandaskan bahwa, asas dasar hubungan (asas al-'alaqah) antara muslim dan non-muslim bukanlah hubungan konflik atau perang (hirabah) melainkan hubungan saling memberikan keselamatan (musalamah). Artinya, hukum asal hubungan antara muslim dan non-muslim bukanlah hubungan konflik dan perang, kemudian baru damai setelah terjadi penjanjian keamanan ('aqd al-aman). Akan tetapi, hukum asal hubungan antara muslim dan non-muslim adalah hubungan damai dan saling memberikan keselamatan, kemudian perang baru diizinkan apabila terdapat faktor-faktor eksternal yang menyulutnya. Pandangan seperti inilah yang di-tarjih dalam kitab Takmilah alMajmu' ${ }^{7}$
Tujuan fundamental dari jịad bukanlah untuk membunuhi nonmuslim, melainkan Untuk menunjukkan jalan hidayah. Apabila jalan hidayah bisa ditunjukkan melalui alternatif-altematif damai tanpa pertumpahan darah, seperti melalui pendidikan, penelitian, dialog, dan sebagainya, maka altematif damai itulah yang harus ditempuh. Sebab, tinta ulama lebih utama daripada darah syuhada.

Apabila kita membaca sejarah Islam di masa hidup Nabi Muhammad saw. secara seksama, kita akan mendapati dari 27 peristiwa perang yang diikuti Nabi (ghazwah) dan 36 ekspedisi perang yang tidak diikuti Nabi (sariyyah), tidak ada satupun yang bersifat ofensif. Semua perang di era Nabi tersebut bersifat defensif, yakni perang untuk membela dan mempertahankan diri dari serangan musuh yang merintangi dakwah dan menghalangi kebebasan beragama. Memahami jihad sebagai manifestasi dari hifzh ad-din, harus merujuk pada peperangan di era Nabi ini, bukan peperangan umat Islam setelah era Nabi. Sebab peperangan umat Islam yang 
terjadi setelah masa hidup Nabi, lebih diwarnai oleh unsur-unsur politik.

Motif peperangan di era Rasulullah yaitu untuk mempertahankan diri dari serangan musuh yang merintangi dakwah dan menghalangi kebebasan umat Islam memeluk agamanya, bukan untuk tujuan memaksa seseorang untuk memeluk Islam. Rasulullah mendakwahkan Islam dengan ketajaman dalil dan burhan, akhlak mulia dan perasaan kasih sayang (syafaqah) kepada umatnya, bukan dengan memaksa orang di bawah todongan senjata.

Karakter jihad yang defensif untuk himayah ad-da'wah dan kebebasan beragama seperti inilah manifestasi jihad sebagai bagian dari hifzh ad-din.

\section{b. Kebebasan Beragama}

Kebebasan beragama memiliki dua pengertian aplikatif. Pertama, tidak ada paksaan bagi non-muslim untuk masuk dan memeluk agama Islam. Kedua, bebas bagi muslim untuk keluar dari agama Islam dan pindah ke agama lain atau menjadi atheis. Dalam wacana klasik, pengertian yang pertama barangkali masih bisa diterima, sebab masalah keimanan adalah masalah yang bersumber dari hati nurani yang butuh ketulusan dan keikhlasan. Mustahil memaksa seseorang yang tidak atau belum bisa meyakini kebenaran Islam sebagai pilihan kepercayaan untuk masuk dan memeluknya secara tulus. Menanamkan ajaran Islam dengan paksaan, tidak akan membentuk jiwa seorang Muslim sejati. Hasil dari pemaksaan hanya akan melahirkan muslim-muslim yang hipokrit (munafiq). ${ }^{8}$ Kebebasan beragama, dalam pengertian tidak ada paksaan bagi non Muslim untuk memeluk agama Islam, sehingga konsekuensinya umat Islam dilarang memaksa non-muslim untuk masuk Islam, adalah konsep yang diajarkan oleh Islam sejak awal. Yang dicita-citakan Islam adalah hubungan antar umat beragama yang rukun dan dialogis, bukan pertikaian dan konflik. Karakter semua agama memang misionaris, termasuk agama Islam. Yakni agama dakwah untuk menyeru umat manusia memeluk agamanya. Akan tetapi, dakwah harus bebas dari segala bentuk pemaksaan. Dakwah memang kewajiban agama, namun Islam tidak mengizinkan dakwah dengan 
menggunakan cara-cara pemaksaan. Dakwah yang diajarkan Islam adalah dakwah dengan pendekatan dalil dan burhan, bukan dengan pedang dan aliran darah. Dakwah yang diajarkan Islam adalah dakwah yang humanis, elegan dan penuh hikmah.

Sedangkan kebebasan agama dalam pengertian yang kedua, yakni bebas bagi Muslim untuk keluar dari agama Islam dan pindah ke agama lain atau atheis, agaknya belum populer dalam wacana ulama klasik. Kebebasan beragama dalam pengertian seperti ini, sangat perlu untuk diwacanakan, setidaknya karena tiga alasan, yakni alasan secara ideologis, alasan secara psikologis, dan alasan secara sosiologis.

Secara ideologis, ajaran Islam jelas mengusung kebebasan beragama sebagaimana ulasan di atas. Islam sangat tidak membenarkan segala bentuk pemaksaan dalam urusan beragama.

Secara psikologis. seseorang yang merasa tidak menemukan kebenaran dalam Islam. pasti batinnya akan berontak ketika dipaksa untuk tetap meyakini Islam dan diancam hukuman mati ketika keluar islam. Sebab, tak mungkin seseorang hidup dengan sehingga konflik berdarah yang kepercayaan yang tidak diyakininya. mengatasnamakan agama bisa dihindari
Kalaupun toh ia tetap memeluk islam, pasti hanya ekspresi kepalsuan atau kemunafikan sekedar untuk menyelamatkan diri dari hukuman mati. Tentu Islam tidak menghendaki keagamaan seseorang seperti ini.

Sedangkan secara sosiologis, kebebasan beragama dengan dua pengertiannya di atas, akan menguntungkan semua agama tanpa terkecuali, termasuk islam. Kompetisi antar agama dalam berdakwah akan berlangsung damai dan dialogis. Bahkan ketika umat Islam berada pada posisi minoritas, akan leluasa menjalankan ritual agamanya tanpa gangguan yang mungkin muncul karena tekanan atau dominasi non-muslim.

Prinsip kebebasan beragama akan memberi kesempatan manusia untuk memilih agama sesuai hati nuraninya secara tulus, ikhlas, dan bertanggung jawab dengan konsekuensi dari pilihannya itu, tanpa paksaan dan ancaman dari pihak manapun. Prinsip kebebasan agama juga mengajarkan kepada manusia akan pentingnya nilai humanisme, kerukunan, penghargaan dan penghormatan kepada orang lain, 
dari kehidupan manusia. Dan inilah melakukan kejahatan serupa, sehingga makna kebebasan agama sebagai bagian dengan sanksi qișas, keberlangsungan dari hifzh ad-din. ${ }^{9}$

\section{Hifzh al-nafs}

Eksistensi agama sebagai petunjuk kehidupan, tidak akan berarti tanpa eksistensi manusia sebagai pemeluknya. Karena itu, Islam memberlakukan perlindungan terhadap keberlangsungan hidup manusia (hifzh al-nafs). Islam adalah satu-satunya agama yang paling tegas dalam menyuarakan perlindungan terḥadap nyawa.

Manifestasi dari proteksi jiwa ini dapat dilihat dari anjuran Islam untuk memperbanyak keturunan lewat ikatan pernikahan dan melarang semua bentuk tindakan yang dapat mengancam atau membahayakan nyawa, dengan memberikan sanksi seberat-beratnya terhadap orang yang melakukan pembunuhan. Islam memberlakukan sanksi berupa qișas pada pelaku tindak kriminal pembunuhan yang disengaja ('amdu mahdhin). Dengan sanksi qișas, diharapkan akan memberikan efek jera atau minimal menanamkan rasa takut terhadap orang lain yang hendak hidup pemeluk agama tetap terpelihara, dan kelestarian agama tetap berlangsung. ${ }^{10}$

Ibnu Manzur dalam kitabnya Lisan al-'Arab menyebutkan, qișas adalah suatu hukuman yang ditetapkan dengan cara mengikuti bentuk tindak pidana yang dilakukan. Al-Quran sendiri memberikan isyarat bahwa yang dimaksud dengan qișas adalah sanksi hukum dengan semirip mungkin terhadap tindak pidana yang dilakukan. ${ }^{11}$

Dengan pengertian demikian, dapat dipahami bahwa spirit dari qișas selain untuk menjadi tindakan pencegahan juga untuk menegakkan keadilan. Yaitu menegaskan adanya konsekuensi yang serupa dengan tindak kejahatan yang dilakukan.

Dalam Islam qișas ditetapkan sebagai hukuman kasus pembunuhan. Hanya Saja, dalam kasus pembunuhan yang disengaja ('amdu mabdhin), disamping qișas, islam juga menawarkan opsi hukuman diyat. Diyat adalah sebuah kompensasi yang harus dibayar pelaku 
pembunuhan setelah mendapatkan mengajarkan keadilan melalui tuntutan ampunan ('afwu) dari pihak korban. qișas saja, melainkan Islam lebih Hukuman diyat inilah yang lebih menekankan sikap yang mencerminkan diprioritaskan dalam Islam. Sebab selain keihsanan melalui pemberian ampunan sebagai bentuk keringanan dan kasih ('afwu) terhadap pelaku pembunuhan sayang agama terhadap pemeluknya, pengampunan yang terdapat di dalam diyat mencerminkan sikap ihsan yang lebih utama dari sikap menunutut keadilan dalam qișas. $^{12}$

Spirit diyat dalam melindungi jiwa dengan tuntutan diyat. Qișas atau diyat adalah termasuk hak adami, dalam hal ini adalah hak korban. Sehingga penerapan atau tidakya, sepenuhnya menjadi kewenangan pihak korban, bukan pihak ketiga termasuk pemerintah.

lebih nyata dibanding qișas. Apabila menerapkan qișas akan kehilangan dua nyawa (nyawa korban dan pelaku), maka dengan diyat hanya akan kehilangan satu nyawa saja, yaitu nyawa korban.

Pendekatan maqashid asy-syari'ah, pemberlakuan qișas masih terdapat kekurangan. Qișas yang sejatinya difungsikan untuk melindungi nyawa, namun pada praktiknya justru menghilangkan nyawa. Itulah sebabnya hukuman diyat yang memiliki spirit ihsan lebih diprioritaskan di dalam Islam daripada qișas yang memiliki spirit keadilan.

Dari ulasan di atas membuat pandangan bahwa, dalam hukuman kasus pembunuhan, Islam bukan hanya

\section{Hifzh al-'aql}

Perlindungan intelektual (akal) merupakan prioritas terpenting setelah perlindungan agama dan nyawa. Karena akal adalah wadah untuk menampung taklif agama. Tanpa akal, pemeluk agama tidak akan bisa menerima beban taklif agama, yang berupa kewajibankewajiban dan larangan-larangan. Tanpa akal, manusia tidak ubahnya dengan makhluk-makhluk lain yang tidak mukallaf. Faktor inilah yang mendasari agama mengharamkan segala tindakan yang berpotensi menghilangkan kesadaran dan kecakapan intelektualitas, serta menganjurkan untuk memberdayakan pemikiran dengan 
berpikir kritis. Islam mengharamkan mengkonsumsi minuman keras, sabusabu, ekstasi, dan lain sebagainya sebagai bentuk penjagaan terḥadap kontrol dan kesadaran akal (hifzh al-'aql).13

Minuman keras atau sejenisnya, memang tidak semua agama sepakat mengatakannya sebagai sesuatu yang tabu atau dilarang. Dalam Islam sendiri, sejarah pengharaman khamr berlangsung secara bertahap. al-Quran membutuhkan waktu setidaknya sampai tiga kali untuk mencapai hukum final meminum khamr, yakni haram. Tahapan ini lebih karena mempertimbangkan aspek psikologis sosial, dimana khamr sudah menjadi bagian dari tradisi yang begitu lekat dalam kehidupan masyarakat. Pada awalnya, al-Quran menyatakan bahwa khamr sebagai karunia dan rezeki yang baik (Q.S. An-Nahl: 67), kemudian turun ayat yang menyatakan bahwa manfaat khamr tidak sebanding dengan bahaya yang ditimbulkannya (Q.S. Al-Baqarah: 219). Yang terakhir, turunlah ayat yang secara tegas menyatakan bahwa khamr adalah minuman keji dan perilaku setan. ${ }^{14}$

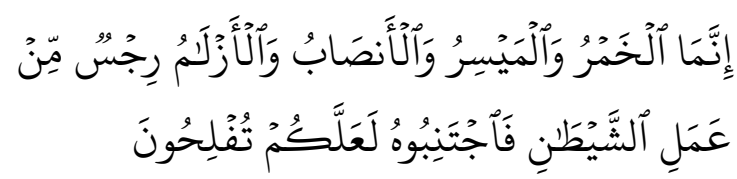

Terjemahnya: Sesungguhnya (meminum) khamar, berjudi, (berkorban untuk) berhala, mengundi nasib dengan panah, adalah termasuk perbuatan syaitan. Maka jauhilah perbuatan-perbuatan itu agar kamu mendapat keberuntungan (Q.S. Al-Maidah: 90).

Kendati hukum khamr dalam Islam tegas diharamkan, akan tetapi hukuman untuk peminum khamr masih terjadi perselisihan di antara ulama. Pasalnya, tidak ada aturan tertulis dalam al-Quran mengenai hukuman yang harus dijatuhkan untuk peminum minuman keras. Sebagai solusi dari kekosongan hukuman pemabuk ini, pasca Nabi Muhammad saw wafat, para sahabat menerapkan hukuman yang beragam. Sebagian menghukum dengan memukul menggunakan pelapah kurma, yang lain dengan sandal dan ada pula yang menggunakan tangan kosong. ${ }^{15}$

Dalam literatur klasik, terjadi perbedaan pendapat ulama dalam menetapkan hukuman bagi peminum khamr.
13 Tim Forza Pesantren, Ijtihad Politik Islam Nusantara, 100
14 Tim DIFA '07, Manhaj Solusi Umat, (Kediri: Lirboyo press, 2007), 233.

15 Ibid, 234 
1. Hanya boleh dipukul dengan perjalanan sejarahnya, hukuman ini juga menggunakan sandal, ujung kain atau masih simpang siur. Dari keterangan Ibn tangan kosong.

Syihab, Nabi hanya memerintahkan

2. Hukuman cambuk, berdasarkan Sahabat yang kebetulan berada di tempat keputusan para Sahabat dan kejadian perkara untuk memukulnya, diterapkan pada era kepemimpinan tanpa menjelaskan secara spesifik berapa Abu Bakar sampai 'Ali bin Abi jumlah pukulan tersebut. ${ }^{19}$ Lalu di masa Thalib. ${ }^{16}$

3. Keduanya boleh diterapkan, dengan berpijak pada kedua dalil yang digunakan oleh pendapat pertama dan pendapat kedua sekaligus (pendapat paling kuat).

Melihat kenyataan di atas, hukuman ini tidak bisa distatuskan sebagai hadd. Sebab hadd adalah istilah hukuman yang bersifat pasti dan jelas serta ditetapkan oleh syariat. ${ }^{17} \mathrm{lbrahim}$ alBajury menyatakan, hukuman dalam pengertian hadd harus ditetapkan oleh syariat dan bersifat absolut, tidak boleh dikurangi atau ditambahi. ${ }^{18}$ Sementara dalam kasus mabuk minuman keras, alQuran tidak menentukan baik jenis hukuman atau jumlahnya. Dalam kepemimpinan Abu Bakar ra., pukulan itu ditetapkan sebanyak 40 kali. Kemudian Umar ra. menetapkan jumlah pukulan dalam satu kali hukuman sebanyak 80 kali. Dan ketika Ali ra. menjadi khalifah, hukuman kembali ditetapkan menjadi 40 kali cambukan. ${ }^{20}$ Karena itulah, hukuman menghilangkan kesadaran akal. baik melalui minuman keras, sabu-sabu, ekstasi atau jenis lainnya, bukan termasuk kategori hadd, melainkan hanya berstatus ta'zir yang penerapannya menjadi otoritas pemerintah, berdasarkan tuntutan kemaslahatan yang menjadi maqashid asysyari'ah.

\section{Hifzh al-nasl}

${ }^{16}$ Ibn Hajar al-Asqalani, Fath al-Bari; Syarh Shahih Bukhari, (Lebanon: Dar al-Kutub alIlmiyah, 2009), 534

${ }^{17}$ Cyril Glasse, Ensiklopedi Islam (Ringkas), (Jakarta: Rajawali press, 2002), 111

${ }^{18}$ Ibrahim al-Bajury, al-Bajury, 'ala Syarh Ibn Qasim al-Ghazzy, (Lebanon:Dar al-Kutub alIlmiyah, 2005), 336

${ }^{19}$ Ibn Hajar al-Asqalani, Fath al-Bari; Syarh Shahih Bukhari, 536

${ }^{20}$ Jalaluddin Muhammad bin Ahmad alMahally, Syarh al-mahally, (Lebanon: Dar el-Fikr, 2006), 205 
Hifzh al-nasl adalah perlindungan genetik, garis nasab atau keturunan. Dalam aplikasinya, hifzh an-nasl memiliki dua pengertian. Pertama, melindungi dari kepunahan generasi atau keturunan (ta'thil an-nasl). Dan kedua, melindungi dari percampuran atau ketidakjelasan garis nasab (ikhtilat an-nasab). Pada pengertian kedua ini, hifzh an-nasl dianggap sebagai prinsip kehidupan yang primer (dharuriyah). Sebab ketidak jelasan garis nasab, dapat menimbulkan sikap acuh dan tidak peduli. Artinya, seorang anak yang terlahir tanpa memiliki garis nasab yang jelas, maka tidak ada yang wajib merasa peduli untuk bertanggug jawab terḥadap keberlangsungan hidupnya. Dan hal ini sangat berbahaya bagi tatanan sosial, bahkan bagi keberlangsungan kehidupan itu sendiri. Karena itulah, Islam memberikan perlindungan terhadap genetik atau garis keturunan (hifzh alnasl). ${ }^{21}$

Manifestasi dari hifzh an-nasl ini, diwujudakan Islam dengan memberikan perlindungan dari sisi menjaga kelestariannya (janib al-wujud), seperti Islam menganjuran pernikahan, memperbanyak keturunan, dan sebagainya. Manifestasi hifzh an-nasl juga diwujudkan islam dengan memberikan perlindungan dari sisi menjaga ancaman yang dapat merusaknya (janib al-'adam), seperti islam melarang aborsi, melarang pengangkatan rahim, melarang perzinahan, dan lain-lain, yang semuanya disyariatkan demi menjaga genetik atau garis keturunan. ${ }^{22}$

Islam sangat keras melarang hal-hal yang dapat merusak garis nasab atau keturunan, karena itulah Islam mengharamkan perzinahan.

Dalam terminologi Islam, zina adalah perbuatan seorang yang memasukan alat kelaminnya pada alat kelamin lawan jenisnya tanpa ikatan pernikahan yang sah, dan tidak dilakukan atas dasar syubhat.

Zina dalam pandangan Islam, bahkan dalam pandangan semua agama, dianggap sebagai perbuatan yang kotor, keji dan amoral, baik dilakukan secara paksa atau atas dasar suka sama suka. Dalam pandangan semua agama, hubungan badan tanpa melalui ikatan yang sah, adalah perbuatan keji yang 
tidak manusiawi dan hanya pantas jelas (qhat'iy ad-dalalah). Dalam teori ușul dilakukan oleh binatang. fiqih, tidak ada ruang untuk melakukan

\section{Sebagaimana}

agama-agama

sebelumnya, Islam juga memberlakukan hukuman yang keras kepada orang yang melakukan perzinahan. Dalam syariat Islam, apabila orang yang zina berstatus gair muhșan (belum pernah berhubungan badan dalam ikatan yang sah), maka dijatuhi hukuman cambuk 100 kali dan diasingkan (taghrib). Dan apabila berstatus muhșan (sudah pernah berhubungan badan dalam ikatan yang sah), maka dikenakan hukuman rajam. Kendati ayat yang berbicara hukuman rajam di atas dianulir (mansukh), namun para ulama (kecuali dari kalangan Khawarij) tetap sepakat (ijma') untuk memberlakukannya. Ijma' ulama untuk memberlakukan sanksi rajam ini berdasarkan Hadis dan tindakan Sahabat (fi'l ash-shababy). Diantara hadits yang membicarakan rajam adalah riwayat dari Abu Ubaidah yang menurut sebagian ulama digunakan sebagai penjelas (mubayyin) ayat al-Quran.

Dengan demikian, hukuman rajam, selain didasarkan pada ijma' ulama, juga didasarkan pada nash agama yang sangat penafsiran-penafsiran (ijtiḥad) terḥadap naș agama yang qhat'iy ad-dalalah, sebab tidak terdapat alternative-alternatif interpretasi. $^{23}$ Namun demikian, sekalipun sanksi zina secara dalil bersifat rigid, akan tetapi dalam tataran praktis, hukuman zina tidak seharusnya diformalisasikan menjadi hukum positif negara. Ada beberapa pertimbangan yang mendasari hal ini.

Zina merupakan tindak pidana yang berhubungan dengan hak Allah (haqqullah). Haqqullah adalah segala aturan hukum yang diberlakukan demi terciptanya kemaslahatan umum. ${ }^{24}$ Halhal yang berhubungan dengan haqqullah, dibangun atas dasar prinsip musamahah dan musahalah, yakni spirit untuk memberi keringanan dan kemudahan hukuman. Sebab urusan-urusan yang berhubungan dengan haqqullah, bisa dilakukan pertaubatan langsung kepada Allah. Lantaran itulah, syarī'at Islam memberi anjuran kepada orang yang melakukan tindak pidana yang berhubungan dengan haqqullah, seperti berzina, mencuri, dan sebagainya, untuk 
merahasiakan (satru) dari ekspos publik, belum pemah ditemukan kasus dan cukup melakukan pertaubatan perzinahan yang dapat memenuhi kepada Allah. Bahkan dalam kasus persyaratan dan ketentuan-ketentuan seseorang yang telah mengaku tersebut. Pada masa Nabi, hukuman melakukan perzinahan di depan hakim, rajam yang dijatuhkan kepada pelaku disunnahkan untuk mencabut zina, seluruhnya ditetapkan berdasarkan pengakuannya. Karena yang paling pengakuan (iqrar) dari pelaku zina esensial dalam kasus yang berhubungan sendiri, bukan berdasarkan persaksian dengan haqqullah bukanlah pelaksanaan (bayyinah). Kalaupun ada saksi yang hudud-nya, melainkan pertaubatannya. melihat kasus perzinahan, juga tidak Dalam menetapkan kasus perzinahan sehingga bisa dijatuhi sanksi zina (rajam atau dera dan diasingkan), dibutuhkan syarat dan ketentuan yang sangat ketat dan sulit untuk dipenuhil. Yaitu harus ditetapkan oleh empat orang saksi yang adil dan melihat kasus perzinahan secara langsung dan dengan mata kepala sendiri atau kasus perzinahan ditetapkan berdasarkan pengakuan (iqrar) pelakunya sendiri. Syarat-syarat demikian, tentu sangat sulit dipenuhi. Apalagi empat saksi tersebut bisa saja menjadi fasiq (sehingga persaksiannya dianggap tidak sah) apabila motif menyaksikan kasus perzinahan bukan untuk tujuan memberikan persaksian di pengadilan. positif suatu negara. Dalam kasus Sepanjang sejarah pengadilan Islam, perzinahan, memberikan kesempatan 
pelaku untuk bertaubat Iebih dianjurkan ketimbang menjatuhkan sanksi kepadanya. Nabi sendiri berkali-kali berusaha menghidarkan hukuman zina kepada para sahabat yang mengaku melakukan perzinahan di hadapan beliau. ${ }^{26}$

\section{Hifzh al-māl}

"Harta bukan segalanya, tapi segalanya butuh harta", pernyataan itu barangkali yang paling representatif untuk menggambarkan betapa fitalnya arti harta atau materi bagi kelangsungan kehidupan manusia. Harta berfungsi sebagai sarana untuk mencukupi kebutuhan primer, sekunder bahkan tersier kehidupan. Tanpa keberadaan harta, bukan hanya akan mengancam kelangsungan tata kehidupan semata, bahkan keagamaan seseorang juga bisa terancam.

Islam menilai harta sebagai salah satu elemen kehidupan yang sangat fital, sehingga Islam memberikan perlindungan terhadap harta (hifzh almāl). Dalam ajaran Islam, manifestasi perlindungan harta diwujudkan dalam banyak hukum. Diantaranya, larangan memakan harta orang Iain dengan jalan batil seperti mencuri, merampok, membegal, mencopet, riba, curang dalam bisnis, mengurangi timbangan, dan sebagainya.

Islam juga memberikan larangan mentasarufkan harta bagi mahjur 'alaih (orang yang dibekukan tasarufnya), larangan untuk tabżir al-māl (menghambur-hamburkan harta), larangan untuk id $a^{\prime} a h$ al-māl (menyianyiakan harta), larangan untuk berlaku israf (berlebih-lebihan atau boros), dan sebagainya, semuanya demi memberikan perlindungan terḥadap harta (hifzh almāl).

Khusus untuk kejahatan pencurian, syariat memberikan hukuman yang keras, yaitu hukuman potong tangan apabila nilai barang yang dicuri mencapai satu nishab, yaitu seperempat (1/4) dinar (kurang lebih 8,145 gram emas).

Hukuman keras ini, karena modus dalam kejahata pencurian dilakukan secara tersembunyi (khufyah), sehingga aksi kejahatannya sulit untuk dicegah menggunkan kekuatan. Berbeda dengan modus kejahatan perampokan atau 
pembegalan, dimana aksi kejahatannya atau tingkat kesejahteraan ekonomi dilakukan secara terbuka (jahrah), masyarakat yang sangat rendah. Dalam sehingga aksinya bisa dicegah keadaan paceklik atau seperti ini, menggunakan kekuatan. Karena sulitnya pemberlakuan hukuman potong tangan mencegah aksi kejahatan pencurian ini hanya akan menimbulkan mafsadah, menggunakan kekuatan, maka syariat yakni akan semakin menyengsarakan memberi hukuman secara khusus, dan menambah penderitaan hidup berupa potong tangan untuk kasus masyarakat. Oleh karena itulah, Sahabat pencurian yang telah mencapai nilai satu Umar ketika masa-masa krisis. tidak nishab. ${ }^{27}$

memberlakukan hukuman potong

Kendati hukuman petang tangan tangan.

bagi pencuri didasarkan pada dalil al-

Penerapan hukuman potong Quran, akan tetapi dalam penerapannya tetap harus mempertimbangkan kemaslahatan yang menjadi nilai-nilai universal syariat (maqashid asy-syari'ah), sehingga hukuman potong tangan yang pada dasarnya disyariatkan untuk kemaslahatan perlindungan harta (hifzh al-māl), tidak justru menimbulkan mafsadah lain yang lebih besar. Apabila hukuman potong tangan dalam praktiknya justru akan menimbulkan mafsadah lain yang lebih besar, maka hukuman potong tangan bagi pencuri tidak boleh dilakukan.

Gambaran hukuman potong tangan yang tidak maslahat ini. adalah seperti dalam masa-masa krisis ekonomi tangan bagi pencuri yang disebutkan dalam al-Quran, hanya tepat diberlakukan terhadap kasus pencurian yang murni didasari motif keserakahan. Kasus-kasus pencurian yang didasari oleh desakan kemiskinan, yang disebabkan oleh krisis ekonomi atau karena pemerintah belum berhasil menyejahterakan kehidupan rakyatnya, maka hukuman potong tangan bagi pencuri tidak akan memberi dampak kemaslahatan. Sebab, dalam kondisi kesejahteraan ekonomi masyarakat yang masih rendah, kasus pencurian tidak murni didasari oleh motif kejahatan atau keserakahan, melainkan lebih karena desakan kebutuhan hidup. Kondisi 
seperti ini dalam Wacana fuqaha' dianggap bisa menggugurkan hukuman potong langan karena faktor syubhat almilk, yakni kondisi darurat yang memperbolehkan seseorang mengambil harta orang lain secukupnya. ${ }^{28}$

Hukuman potong tangan hanya akan merefleksikan kemaslahatan apabila sebuah negara telah dapat menjamin kemakmuran dan kesejahteraan hidup rakyatnya. Dalam kondisi kehidupan masyarakat yang sejahtera, aksi pencurian harta orang lain sangat tidak beralasan. Ahli psikologi juga mengatakan, aksi pencurian pada masa makmur dan mudah mencari pekerjaan halal, lebih didorong oleh nafsu serakah dan kelainan mental daripada didorong oleh kebutuhan hidup. Dalam kondisi masyarakat yang sejahtera demikian, pemberlakuan hukuman potong tangan akan memiliki dampak kemaslahatan, yakni akan menjadi shock therapy yang berfungsi sebagai edukasi, sanksi, tindakan preventif, dan jaminan ketertiban dan keamanan secara luas.

Dalam tingkat kesejahteraan hidup masyarakat yang masih rendah, upaya mengentaskan kemiskinan dan menyejahterakan kehidupan rakyat jauh lebih penting daripada menegakkan hukuman potong tangan dengan membuntungi tangan-tangan pencuri yang justru akan semakin menambah penderitaan dan kesengsaraan rakyat. Apabila al-Quran secara harfiyah meginstruksikan untuk memotong tangan pencuri agar menjadi buntung sehingga diharapkan tidak lagi bisa mencuri, maka mengupayakan pengentasan kemiskinan dan menyejahterakan kehidupan masyarakat sehingga tidak ada lagi alasan untuk melakukan pencurian, maka upaya demikian bisa jadi merupakan interpretasi dari perintah memotong tangan secara ma'nawi. Dengan kata lain, perintah potong tangan tidak diinterpretasikan dengan memotong tangan secara fisik yang digunakan mencuri, melainkan diinterpretasikan dengan memotong tangan secara maknawi, yakni kemiskinan yang menjadi pendorong seseorang melakukan pencurian.

Dengan demikian, maka jelaslah bahwa memformalisasikan hukuman potong tangan bagi pencuri menjadi 
hukum positif suatu negara, sangat tidak tepat apabila tidak terlebih dahulu mempertimbangankan kemaslahatankemaslahatan yang menjadi cita-cita dan tujuan dari pensyarīatan setiap hukum Islam (maqashid asy-syari'ah).

\section{Kesimpulan}

Wasatiiyyah melekat pada islam semenjak ia lahir dan akan terus melekat sampai hari kiamat nanti. Dalam sejarahnya, pasca terjadinya perpecahan dalam tubuh umat islam yang melahirkan banyak madzhab dan aliran, sifat Wasatiiyyah melekat pada golongan yang berhaluan Ahlus Sunnah wa aljama'ah, termasuk didalamnya aliran teologi Asy'ariyah dan Maturidiyah.

Maqashid syari'ah muncul akibat perdebatan di antara pakar figh mengenai syari'ah, yang memiliki 'illat (kausa) tertentu ataukah tidak. Perdebatan tersebut menimbulkan berbagai macam aliran tak terkecuali di kalangan ulama' ushul figh. Maghasid al-ahkam dianggap sebagai dasar dalam penetapan suatu hukum, dan dapat dikategorikan sebagai landasan utama dalam hukum. Sebagaimana keterangan mengenai alkulliyyat al-khams beserta batasannya,

hifzh ad-din (perlindungan agama), hifzh an-nafs (perlindungan jiwa), hifzh al-'aql (perlindungan intelektual), hifzh an-nasl (perlindungan genetik), dan hifzh al-māl (perlindungan harta).

\section{Daftar Pustaka}

'Asyur, Thahir Ibn. Maqashid al-Islamiyah as-Syari'ah, Jordania: Dar an-Nafais, 2001

al-Anshari, Abu Yahya Zakariyah. Asnaa al Mathalib, Lebanon: Dar el-Fikr, 2001.

al-Asqalani, Hajar. Fath al-Bari; Syarh Shahih Bukhari, .Lebanon: Dar alKutub al-Ilmiyah, 2009.

al-Bajury, Ibrahim. al-Bajury, 'ala Syarh Ibn Qasim al-Ghazzy, as-Sunan al-Kubra, Maktabah Syamilah, Vol VI

al-Bajury, Ibrahim. al-Bajury, 'ala Syarh Ibn Qasim al-Ghazzy, Lebanon:Dar alKutub al-Ilmiyah, 2005.

al-Mahally, Jalaluddin Muhammad bin Ahmad. Syarh al-mahally, Lebanon: Dar el-Fikr, 2006

ash-Shabuni, Ali. Rawaa'I al-Bayan, Maktabah Syamilah.

As-Sarkhasy, al-Mabsuth li as-Sarkhasy, Maktabah Syamilah, Vol XI

Asy-Syathibi, Abi Ishaq, al-Muwafaqat fi Ushul Asy-Syari'ah, Kairo: Dar alHadits, 2006

az-Zuhaili, Wahbah, Ushul al-Figh alIslami, Damaskus: Dar el-fikr, 2006 
Moderasi Islam dalam Dimensi Berbangsa, Bernegara Dan

Glasse,Cyril. Ensiklopedi Islam (Ringkas), Jakarta: Rajawali press, 2002

Khallaf, Abdul Wahbab. 'Ilm Ushulal-Figh, Haramain, 2004.

Manzur, Ibnu, Lisan al-'Arab, Maktabah Syamilah

Muhajir, Afifuddin. Fiqh Tata Negara, Yogyakarta: Diva press, 2017

Muthi'I, Takmilah al-Majmu',(Maktabah Syamilah),

Tim DIFA '07, Manhaj Solusi Umat, Kediri: Lirboyo press, 2007

Tim Forza Pesantren, Ijtihad Politik Islam Nusantara, Kediri: Lirboyo press, 2015 